\title{
喉頭に発生した悪性線維性組織球腫例
}

\author{
野田 和裕 1$) \cdot$ 宮原 裕 2$) \cdot$ 奥村 新一 3 ) \\ 三代 康雄 ${ }^{4)} \cdot$ 尾崎 康弘 ${ }^{5)}$
}

\section{Malignant Fibrous Histiocytoma of the Larynx ; A Case Report}

\author{
Kazuhiro Noda \\ (Kawanishi City Hospital) \\ Hiroshi Miyahara \\ (Nara Medical University) \\ Shin-ichi Okumura \\ (Osaka Rosai Hospital) \\ Yasuo Mishiro \\ (Osaka University) \\ Yasuhiro Ozaki \\ (Osaka City)
}

Primary malignant fibrous histiocytoma $(\mathrm{MFH})$ of the larynx is extremely rare. We describe a case of a 61-year-old man with a malignant fibrous histiocytoma of the larynx who complained of hoarseness. The tumor was a red smooth mass on the right true vocal cord, which was approximately $0.5 \mathrm{~cm}$ in diameter. Histologic examination revealed $\mathrm{MFH}$. A fronto-lateral vertical partial laryngectomy was performed, and chemotherapy was given post-operatively. There has been no recurrence during the 3 years and 6 months since surgery.

Key words : malignant fibrous histiocytoma, larynx, partial laryngectomy

はじめに

悪性線維性組織球腫 (malignant fibrous histiocytoma, 以下 $\mathrm{MFH}$ と略す) は, 通常は四肢抢よび後腹膜に発生 する軟部悪性腫瘍である。頭頸部原発のものは少な (1)2), しかもそのらちの多くが副鼻腔発生例で1), 喉頭 に発生したものは極めてまれである.

今回我々は, 声門部に原発した MFH の 1 例を経験し たので，若干の文献的考察を加えて報告する.

\section{症例}

患者: 61歳, 男性.

主訴 : 嗄声.

既往歷, 家族歴 : 特記すべきことなし。

現病歴 : 平成 3 年 4 月頃より徐々に嗄声を認め, 9 月 に近医受診し声帯腫湯の診断のもと10月 4 日, 大阪労災 病院耳鼻咽喉科を紹介された。

初診時所見: 右声帯に直径 $0.5 \mathrm{~cm}$ 程度の赤色, 表面 平滑, 半球状の腫瘍を認めた。嗄声を認め, 呼吸困難,

5）大阪市 
臙下困難, その他の自覚症状を認めなかった。頸部リン 節を触知せず，その他耳鼻咽喉科的異常を認めなから た。

経過：平成 3 年10月29日, 喉頭微細術(図 1 ) そて腫瘍 の部分摘出術を施行, 組織診は線維性結節で, 悪性像を 認めなからたため退院した。

その後外来にて経過観察中, 腫痬の残存部位より徐及 に增大傾向を示し, 平成 4 年 2 月 6 日, 11 月 27 日に組織 採取するもいずれも悪性像を認めなかった。しだいに対 側声帯に接するほどの腫瘍増大を示したため, 平成 5 年 1 月12日, 喉頭微細術(図 2 ) そて腫瘍の声带より突出し

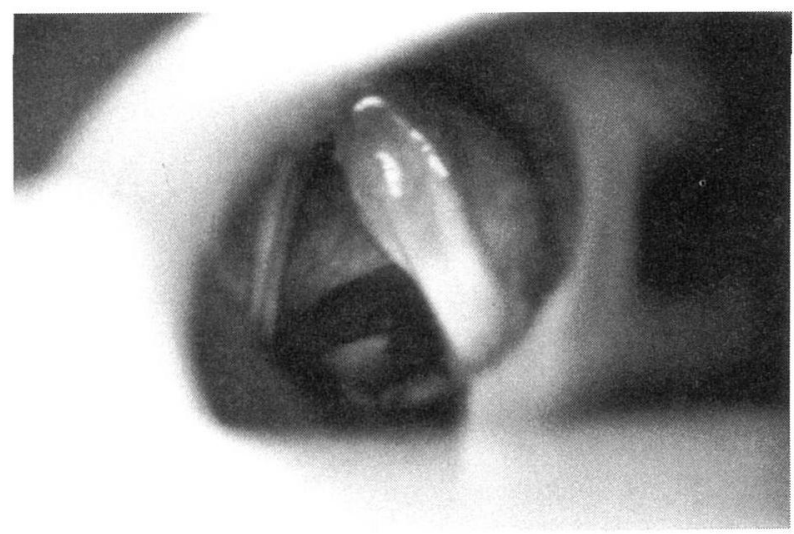

図 1 平成 3 年10月 29 日, 1 回目の喉頭微細術時所見 右声带に直径 $0.5 \mathrm{~cm}$, 赤色, 表面平滑, 半球状, 弾性 硬の腫瘍を認めた。

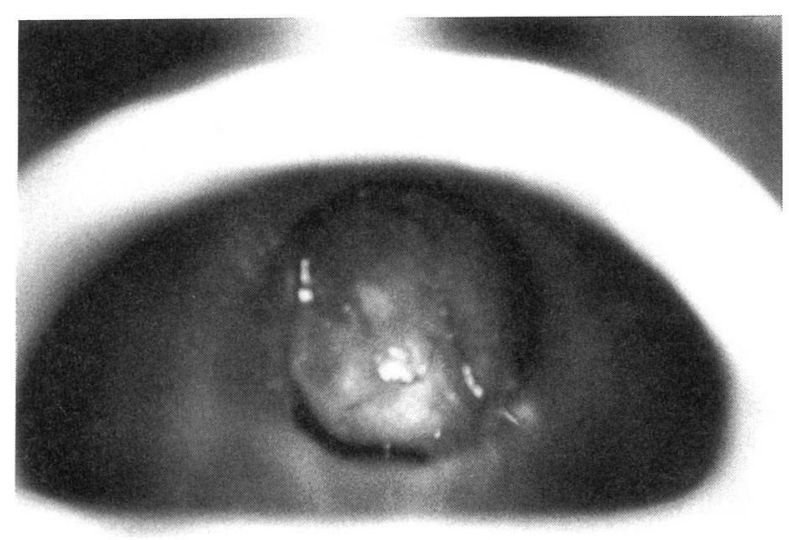

図 2 平成 5 年 1 月 12 日, 2 回目の喉頭微細術時所見 右声帯より発生し，対側声帯に接する活ど，腫瘍が増大 していた. 1 回目の所見と同じく, 赤色, 表面平滑, 弾 性硬であった。
た部分を一塊にて切除, 組織診にて悪性線維性組織球腫 の䛦断を得た。同 3 月 15 日右喉頭垂直部分切除術を施行 した(図 3 ).

手術所見：甲状軟骨前面の一部を切除し，甲状軟骨内 面から喉頭粘膜を剥離した。喉頭粘膜を上端は右喉頭室, 後端は右声帯突起(筋突起は残す), 下端は声門下 $2 \mathrm{~cm}$ 程度, 前端は前交連から左声帯の一部に至るまでの範团 で切除した．声帯の再建は右前頸筋を甲状軟骨下方の高 さで切断し，下端を縫合する方法で行った．

病理組織所見 : 硝子様変化を伴う線維性の部分が㘯り, 一部には細胞質が多くて核異型性の強い組織球様の細胞 を認める(図 $4 \sim 6$ ). 免疫染色では $\alpha 1$-アンチキモトリ プシン, $\alpha 1$-アンチトリプシン, リゾチーム(図 7), ビ メンチンがそれ年れ陽性，S-100蛋白，ケラチンがそれ ぞれ陰性であった。

線維芽様細胞と組織球様細胞を認め, 細胞の異型性と 免疫染色の結果より, MFH と診断した。

術後経過：7月 5 日より CYVADIC (cyclophosphamide, vincristine, doxorubicin, dacarbazine) 3 クール を施行した。

現在まで腫瘍の再発を認めず，発声機能良好で䱏下障 害もない。

\section{考察}

悪性線維性組織球腫は，全身の軟部組織，すなわち四 肢, 軀幹, 後腹膜, 皮虐, 皮下組織などに発生する肉腫

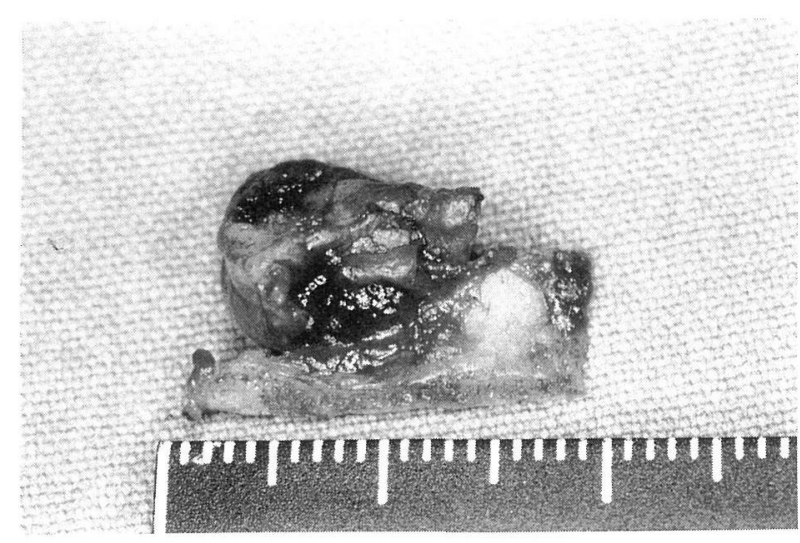

図 3 平成 5 年 3 月 15 日, 右喉頭垂直部分切除術に扣々る摘出 標本. 


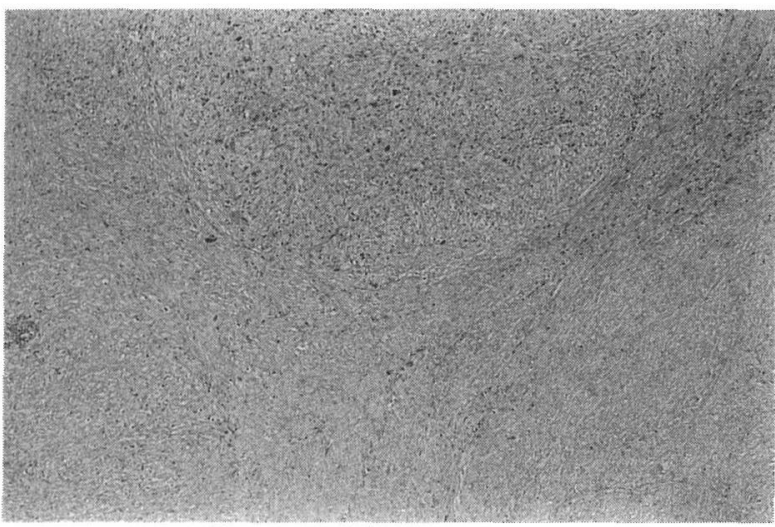

図 4 病理組織所見 $\mathrm{HE}$ 染色 $(\times 50)$

一部に硝子稴变化老伴ら線維性の部分が認められる。

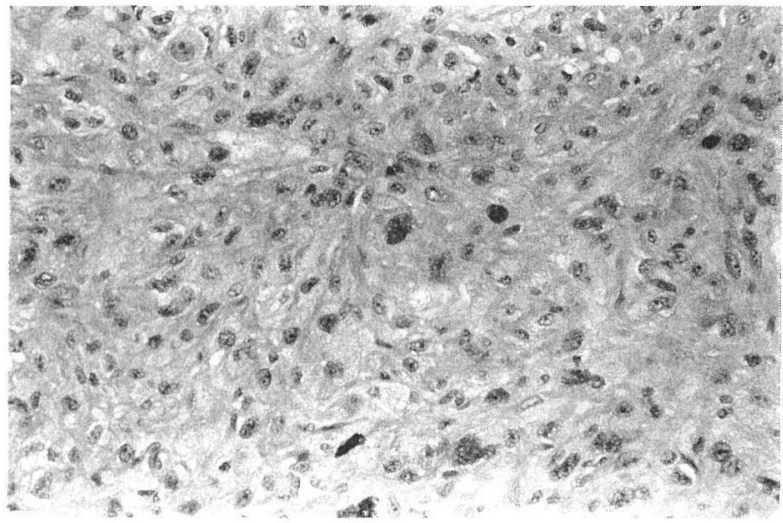

図 5 病理組織所見 HE 染色 $(\times 200)$

細胞質が多く核異型性の強い組織球様の細胞が認められ る.

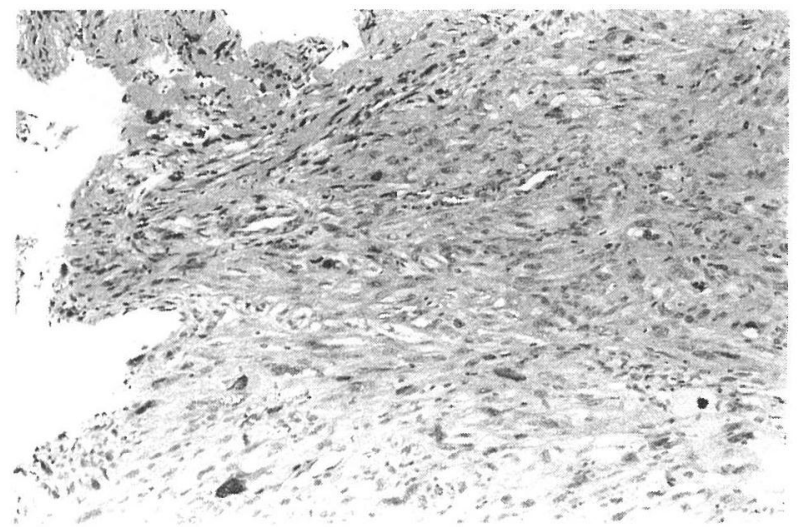

図 6 病理組織所見 $\mathrm{HE}$ 染色 $(\times 100)$ 線維增生が強く核の異型性も認められる。

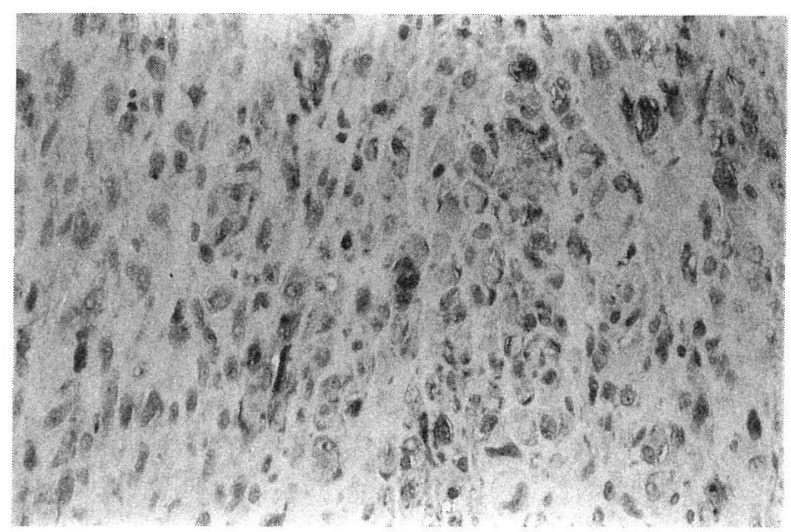

図 7 抗リゾチーム抗体を用いた免疫組織所見 $(\times 200)$

である、以前は比較的少ない腫瘍とされていたが， Weiss ら $^{2)}$ が本腫瘍の判定基準を拡げ， storiform patternを示すものの他, 多形性細胞からなるもの, 粘液 腫状間質を有し細胞に多形性を示すものまで含めたため, 現在では成人悪性軟部腫瘍の中では最も頻度の高い肉腫 である。しかし，発生部位としては四肢，後腹膜が多く， 頭頸部領域の発生頻度は低い3). 頭頸部領域では鼻副鼻 腔に多く認められるが1)，搌頭に発生したものはょれで ある。我々が検索した限りでは, Ferlito ら ${ }^{4)}$ が, 過去 の文献より $\mathrm{MFH}$ に再分類した 5 症例を含め，現在まで 自験例を含め24例報告されている(表 1$)^{4) ~ 22) . ~}$

年龄は 8 歳から68歳(平均 45.3 歳), 男女比は $3: 1$ で, 発生部位は声門上が 6 例, 声帯が 7 例, 声門下が 9 例で ある。

$\mathrm{MFH}$ 全体では，中高蹂者に比較的多々，男性に多い とされるが，喉頭に执いても同様の傾向といえる.

$\mathrm{MFH}$ と鑑別すべき疾患としては，骨肉腫，線維肉腫， 多形性横紋筋肉腫などがある。組織像としては，1)腫 瘍細胞は線維芽細胞様細胞, 組織球様細胞からなり, 他 の特殊な分化を示さない，2)腫瘍細胞に多形成があり， しばしば bizarreな巨細胞の出現を認める。 3 )striform pattern が高頻度に認められる。4) 泡沫細胞, 担鉄細 胞を認めることがある。）種々の程度の炎症性細胞浸 潤を認める。などである゙。。しい でも部位により多彩な組織像を呈することがあり初回診 断が困難なことが多い。また良性悪性を, 組織像だけで 明確に判断することはときに困難で23)，腫瘍の大きさが その性質の判断に有効であり 24)，また転移の有無などに 
表 1 喉頭悪性線維性組織球腫の報告例

\begin{tabular}{|c|c|c|c|c|c|c|c|c|c|}
\hline & 報 告 者 & 報告年 & 年齢 & 性 & $\begin{array}{l}\text { 発生 } \\
\text { 部位 }\end{array}$ & 初 期 治 療 & 再 & 2 次治療 & 初期診 断 \\
\hline $1^{*}$ & Hall-Jones ${ }^{5)}$ & 1972 & 26 & 男 & 声門上 & 喉頭全摘出 & NED 10年** & なし & 巨細胞腫 \\
\hline $2^{*}$ & Rolander $5^{6)}$ & 1972 & 56 & 男 & 声門上 & $\begin{array}{l}\text { 声門上喉頭部分切除, } \\
\text { 頸部郭清 }\end{array}$ & NED & 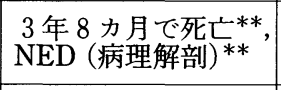 & 異型線維性黄色腫 \\
\hline $3^{*}$ & Coyas 57) & 1974 & 67 & 男 & 声帯 & 腫瘍摘出 & 再発 & $\begin{array}{l}\text { 声帯切除術 RT } \\
\text { 生存 } 8 \text { 年** }\end{array}$ & 悪性巨細胞腫 \\
\hline $4^{*}$ & Canalis $5^{8)}$ & 1975 & 53 & 男 & 声帯 & 部分的核出 & 再発 & $\begin{array}{l}\text { 喉頭全摘 } \\
1 \text { 年 } 2 \text { 月で死亡 }\end{array}$ & 線維性黄色腫 \\
\hline $5^{*}$ & Ribari $5^{9)}$ & 1975 & 35 & 男 & 声門下 & 腫瘍摘出 RT & NED 2 年 & なし & 良性巨細胞腫 \\
\hline 6 & Ferlito $5^{10)}$ & 1976 & 46 & 男 & 喉頭 & 喉頭全摘出 RT & 再発 & $\begin{array}{l}\text { 下咽頭食道摘出 RT } \\
\text { 化学療法 } \\
1 \text { 年 } 2 \text { 月で死亡 }\end{array}$ & 線維肉腫 \\
\hline 7 & Johnson $5^{11)}$ & 1977 & 67 & 女 & 声門下 & 腫瘍摘出 & 再発 & 喉頭全摘生存 5 年** & 平滑筋腫 \\
\hline 8 & Ferlito $5^{12)}$ & 1978 & 58 & 男 & 声門下 & 腫瘍摘出 & 再発 & $\begin{array}{l}\text { 喉頭垂直部分切除, } \\
\text { 啹頭全摘 } \\
1 \text { 年 } 7 \text { カで死亡 }\end{array}$ & 線維性組織球腫 \\
\hline 9 & Ferlito $5^{13)}$ & 1979 & 68 & 男 & 声門上 & 喉頭全摘出 & $\begin{array}{l}\mathrm{NED} \\
1 \text { 年 } 5 \text { カ月 }\end{array}$ & なし 生存 5 年 & 悪性間葉性新生物 \\
\hline 10 & Keenan $5^{14)}$ & 1979 & 22 & 女 & 声門下 & 内視鏡的除去 & 再発 & $\begin{array}{l}\text { 喉頭気管部分切除, } \\
\text { NED } 4 \text { 年** }\end{array}$ & MFH \\
\hline 11 & Ogura $5^{15)}$ & 1980 & 22 & 女 & 声門下 & 気管輪状軟骨部分切除 & NED 4 年 & なし & $\mathrm{MFH}$ \\
\hline 12 & Ogura $5^{15)}$ & 1980 & 28 & 男 & 声門下 & 気管輪状軟骨部分切除 & $\begin{array}{l}\mathrm{NED} \\
2 \text { 年 } 6 \text { 力月 }\end{array}$ & なし & $\mathrm{MFH}$ \\
\hline 13 & Neblett $5^{16)}$ & 1981 & 22 & 女 & 声門上 & 喉頭垂直部分切除 & $\begin{array}{l}\mathrm{NED} \\
1 \text { 年 } 8 \text { 力月 }\end{array}$ & なし 生存 4 年** & 線維性組織球腫 \\
\hline 14 & Ferlito $5^{4)}$ & 1983 & 67 & 男 & 声帯 & 喉頭全摘出 RT & $\begin{array}{l}1 \text { 年11カ月で } \\
\text { 死亡 }\end{array}$ & なし & 悪性新生物 \\
\hline 15 & Ferlito $5^{4)}$ & 1983 & 51 & 男 & 声帯 & 喉頭全摘出 & NED 8 力月 & なし & $\mathrm{MFH}$ \\
\hline 16 & Ferlito $5^{4)}$ & 1983 & 63 & 男 & 喉頭 & 咽喉頭食道摘出 & NED 8 力月 & なし & 紡鍾形細胞肉腫 \\
\hline 17 & Ferlito $5^{4)}$ & 1983 & 8 & 女 & 声門下 & & & & \\
\hline 18 & Ramadass $5^{17)}$ & 1984 & 45 & 男 & 声帯 & 喉頭全摘出 & 記載なし & なし & 線維性組織球腫 \\
\hline 19 & Godoy $5^{18)}$ & 1986 & 26 & 女 & 声門下 & 喉頭全摘出 & NED 6 力月 & なし & $\mathrm{MFH}$ \\
\hline 20 & Majumder $5^{19)}$ & 1989 & 45 & 男 & 声門上 & 喉頭全摘出 RT & NED 1 年 & なし & $\mathrm{MFH}$ \\
\hline 21 & Saha $5^{20)}$ & 1989 & 58 & 男 & 声門上 & RT & 5 カ月で死亡 & なし & $\mathrm{MFH}$ \\
\hline 22 & Bernalde $z ら^{21)}$ & 1991 & 54 & 男 & 声帯 & 喉頭全摘出 & $\begin{array}{l}\mathrm{NED} \\
1 \text { 年 } 3 \text { 力月 }\end{array}$ & なし & $\mathrm{MFH}$ \\
\hline 23 & Scott $5^{22)}$ & 1995 & 38 & 男 & 声門下 & 喉頭全摘出 RT & NED 3 年 & なし & 紡鍾形細胞癌 \\
\hline 24 & 自験例 & 1996 & 61 & 男 & 声帯 & $\begin{array}{l}\text { 喉頭垂直部分切除, } \\
\text { 化学療法 }\end{array}$ & $\begin{array}{l}\mathrm{NED} \\
3 \text { 年 } 6 \text { カ月 }\end{array}$ & なし & 線維性結節 \\
\hline
\end{tabular}

*はFerlito ら4)により, MFH と再診断された症例 NED : no evidence of disease

**はFerlito ら 4 ににより，個人的に再確認されたもの RT：放射線治療

よる総合的な判断が必要なこともある.喉頭においても それは同様であり，表1飞示すように初回診断に执いて $\mathrm{MFH}$ の診断に至らなかった症例が少なくない，我々の
症例も再三の検查にも関わらず確定診断に至らず苦慮し た. 免疫組織化学的手法からは $\alpha 1$-アンチトリプシン, $\alpha 1$-アンチキモトリプシンなどが MFH の組織球分化を 
示す良いマーカーと考光られて扣り25), 本例も $\alpha 1-$ アン チトリプシン， $\alpha 1$-アンチキモトリプシン, リゾチーム， ビメンチンが陽性であった.

$\mathrm{MFH}$ の予後は不良であり，Weiss ら2)の報告による と，44\%に再発，42\%に転移を認め 2 年以内に約 $40 \%$ が 死亡している。転移は肺が最も多く, 肝, 腎, 骨, リン パ節などへの転移も報告されている3)。

治療は, MFH に対しては悪性度から考えて, まず拡 大切除が重要であることで諸家の意見がほぼ一致してい る. 喉頭に拈いても外科的に十分大きく切除することが 必要と考兄られ8), 表 1 に示すように喉頭全摘など拡大 手術が施行されている例が多い. MFH に対して放射線 は有効性が認められない症例が多く26)，化学療法も種々 の多剂併用療法の使用報告があるが，特に有効なものは ないよらである27)。喉頭に扣いてもやはり放射線療法や 化学療法が著効したものは認められなかった。自験例に おいても喉頭全摘が適当と思われたが，患者の納得が得 られず喉頭部分切除術となった。幸い術後 3 年 6 力月の 現在も再発，転移を認めない。

以上我々が経験した喉頭悪性線維性組織球腫の 1 例に ついて報告した。

$$
\text { まとめ }
$$

1) 喉頭に発生した悪性線維性組織球腫のまれな 1 症 例を経験したので，若干の考察を加え報告した。

2 ) 喉頭垂直部分切除術を施行し 3 年 6 力月後の現在 まで経過良好である。

なお，本論文の要旨は, 第245回日本耳鼻咽喉科学会大阪府 地方部会および第56回耳鼻咽喉科臨床学会にて発表した。

\section{参考文献}

1) Barnes L and Kanbour A : Malignant fibrous histiocytoma of the head and neck; a report of 12 cases. Arch Otolaryngol Head Neck Surg $114: 1149 \sim 1156,1988$.

2 ) Weiss SW and Enzinger FM : Malignant fibrous histiocytoma ; an analysis of 200 cases. Cancer $41: 2250 \sim$ 2266, 1978.

3 ）橋本 洋: 悪性線維性組織球腫の臨床病理学的研究. 福岡 医誌 $70 ： 585 \sim 613,1979$.

4 ) Ferlito A, Nicolai P, Recher G, et al : Primary laryngeal malignant fibrous histiocytoma ; review of the literature. Laryngoscope $93: 1351 \sim 1358,1983$.
5 ) Hall-Jones J : Giant cell tumour of the larynx. J Laryngol Otol $86: 371 \sim 381,1972$.

6 ) Rolander T, Kim OJ and Shumrick DA : Fibrous xanthoma of the larynx. Arch Otolaryngol $96: 168 \sim 170,1972$.

7 ) Coyas A, Anastassiades OT and Kyriakos I : Malignant giant cell tumour of the larynx. J Laryngol Otol 88 : 799 803, 1974.

8 ) Canalis R, Green M, Donard H, et al : Malignant fibrous xanthoma of the larynx. Arch Otolaryngol $101: 135 \sim 137$, 1975.

9 ) Ribari O, Elemer G and Balint A : Laryngeal giant cell tumour. J Laryngol Otol $89: 857 \sim 861,1975$.

10) Ferlito A : Simultaneous malignant pleomorphic fibrous histiocytoma and squamous cell carcinoma in situ of larynx. Acta Otorhinolaryngol Belg $30: 390 \sim 397,1976$.

11) Johnson JT and Poushter DL : Fibrous histiocytoma of the subglottic larynx. Ann Otol 86 : 243 246, 1977.

12) Ferlito $A$ : Histiocytic tumors of the larynx. Cancer 42 : $611 \sim 622,1978$.

13) Ferlito A, Recher G, Polidoro F, et al : Malignant pleomorphic fibrous histiocytoma of the larynx. J Laryngol Otol $93:$ 1021 1029, 1979.

14) Keenan JP, Snyder GG and Toomey JM : Malignant fibrous histiocytoma of the larynx. Otolaryngol Head Neck Surg $87:$ 599 603, 1979.

15) Ogura JH, Toomey JM, Setzen $M$, et al : Malignant fibrous histiocytoma of the head and neck. Laryngoscope $90: 1429 \sim 1440,1980$.

16) Neblett LM and Coller FC : Malignant fibrous histiocytoma of the larynx. Am J Otol $2: 163 \sim 166,1981$.

17) Ramadass T, Balasubramaniam VC and Annamalai L : Malignant pleomorphic fibrous histiocytoma of the larynx ; a case report with review of literature. J Laryngol Otol $98: 93 \sim 96,1984$.

18) Godoy J, Jacobs JR and Crissman J : Malignant fibrous histiocytoma of the larynx. J Surg Oncol $31: 62 \sim 65,1986$.

19) Majumder NK, Sharma HS and Srinivasan V : Malignant fibrous histiocytoma of larynx. J Laryngol Otol $103: 219$ $\sim 221,1989$

20) Saha AM, Mukherjee D, Chatterjee DN, et al : Malignant fibrous histiocytoma of larynx. J Indian Med Assoc 3 : 73 74, 1989.

21) Bernaldez R, Nistal M, Kiaser C, et al : Malignant fibrous histiocytoma of the larynx. J Laryngol Otol $105: 130 \sim$ 133, 1991.

22) Scott KM and Carter CS : Malignant fibrous histiocytoma of the larynx; case report and literature review. J Otolaryngol $24: 198 \sim 200,1995$. 
23) Ozello L, Stout AP and Murray MR : Cultural characteristics of malignant histiocytomas and fibrous xanthomas. Cancer $16: 331 \sim 344,1963$.

24) O'Brien JE and Stout AP : Malignant fibrous xanthomas. Cancer $17: 1445 \sim 1458,1964$

25) Kindblom LG, Jacobsen GK and Jacobsen $M:$ Immunohistochemical investigations of tumors of supposed fibroblastic-histiocytic origin. Hum Pathol $13: 834 \sim 840$, 1982.

26）近 芳久, 小原能和, 小笠原眞, 他 : 鼻副鼻腔の悪性線維
性組織球腫.耳鼻 $37: 782 \sim 792,1991$.

27) Kearney MM, Soule EH and Ivins JC : Malignant fibrous histiocytoma ; a retrospective study of 167 cases. Cancer $145: 167 \sim 178,1980$.

$$
\left(\begin{array}{l}
\text { 原稿受付 : 平成 } 8 \text { 年 } 10 \text { 月 } 3 \text { 日 } \\
\text { 原稿採択 : 平成 } 8 \text { 年11月 } 6 \text { 日 } \\
\text { 別刷請求先 : 野田和裕 } \\
\text { ⿳6 } 666-01 \text { 川西市東畦野5-21-1 } \\
\text { 市立川西病院耳鼻咽喉科 }
\end{array}\right)
$$

